\title{
Peran Dukungan Sosial Dalam Peningkatan Motivasi Berprestasi Pada Remaja Dari Keluarga Menengah Kebawah Di Kabupaten Kudus
}

Tri Yaumil Falikah

Program Studi Pendidikan Agama Islam, Universitas Ahmad Dahlan, Indonesia

\begin{tabular}{l} 
Article Info \\
\hline Article history: \\
Received 2020-02-01 \\
Accepted 2020-04-06 \\
\hline
\end{tabular}

\section{Keywords:}

Motivasi Berprestasi

Dukungan Sosial

Remaja

Keluarga Menengah Kebawah

\begin{abstract}
Motivasi berprestasi merupakan faktor yang sangat penting dalam memajukan peradaban bangsa. Salah satu faktor yang mempengaruhi motivasi berprestasi adalah dukungan sosial baik dari keluarga, sekolah, kawan sebaya, dan juga lingkungan hidup. Seabagaimana remaja pada umumnya, dukungan sosial juga sangat diperlukan bagi remaja dari keluarga menengah kebawah agar tetap memiliki motivasi berprestasi. Di Kabupaten Kudus, jumlah penduduk miskin pada tahun 2013 pernah mengalami peningkatan jumlah yaitu 70.100 jiwa. Adapun metode pengumpulan data menggunakan angket yang terdiri dari angket dukungan sosial dan motivasi berprestasi. Analisis data dengan korelasi digunakan untuk mengukur korelasi antara variabel dukungan sosial dengan motivasi berprestasi. Hasil penelitian menunjukkan bahwa dukungan sosial berkorelasi positif signifikan dengan motivasi berprestasi pada remaja dari keluarga menengah kebawah di Kabupaten Kudus. Hal ini ditunjukan dengan besarnya nilai korelasi (R) yaitu sebesar 0.222 dan diperoleh koefisien determinasi (R2) sebesar 0.049, yang mengandung pengertian bahwa pengaruh variabel bebas (dukungan sosial) terhadap variabel terikat (motivasi berprestasi) adalah sebesar $49 \%$, sedangkan sisanya dipengaruhi oleh variabel yang lain.
\end{abstract}

This is an open access article under the CC BY-SA license.

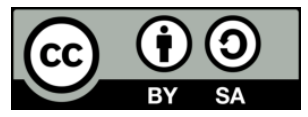

\section{Corresponding Author:}

Tri Yaumil Falikah,

Program studi Pendidikan Agama Islam,

Universitas Ahmad Dahlan,

Email: tri.falikah@pai.uad.ac.id

\section{PENDAHULUAN}

Motivasi berprestasi menjadi faktor yang sangat penting untuk membangun peradaban bangsa termasuk negara berkembang seperti Indonesia. Hal ini selaras dengan pendapat MC. Clelland yang menyatakan bahwa negara-negara yang perekonomiannya maju, masyarakat di dalamnya pasti memiliki dorongan berprestasi tinggi (Gunarsa, 2008: 64).

Motivasi berprestasi individu mengalami perubahan sesuai dengan bertambahnya usia. Lili (2005: 39) menyebutkan bahwa motivasi berprestasi dipengaruhi oleh beberapa faktor, yaitu: keluarga dan kebudayaan (Family and cultural); konsep diri (self concept); jenis kelamin (sex roles); serta pengakuan dan prestasi (recognition and achievement). Sedangkan Sri Harimi (2012: 3) secara lebih khusus menyebutkan bahwa faktor lain yang dianggap mempengaruhi motivasi berprestasi siswa adalah dukungan sosial. Narulita (2005: 5) menyatakan bahwa Dukungan sosial baik dari masyarakat maupun segala bentuk perhatian yang diberikan oleh orang tua, merupakan salah satu faktor pendukung kesuksesan prestasi dan mampu meningkatkan motivasi berprestasi remaja dalam proses belajar. Selain itu, Heejung dalam (Bonanno, 2007: 671) melaporkan bahwa dukungan sosial merupakan salah satu faktor penting yang bisa dijadikan sebagai bentuk dorongan untuk mereduksi tingkat stress dan emosi 
negatif seseorang. Oleh sebab itu, dukungan sosial sangat diperlukan oleh anak usia remaja yang menjadi tunas bangsa untuk meningkatkan motivasi berprestasi dalam diri mereka.

Dukungan sosial sebagai faktor yang dapat meningkatkan motivasi berprestasi ini menjadi lebih dibutuhkan lagi oleh remaja dari keluarga menengah kebawah. Hal ini disebabkan kondisi psikologi remaja yang dibesarkan di kalangan keluarga menengah kebawah cenderung merasa tidak percaya diri, apatis, dan sikap negatif lainnya. Berdasarkan hasil observasi dan wawancara 49 remaja dari keluarga miskin di Kabupaten Kudus, 20 diantaranya merasa tidak percaya diri dengan teman-teman di sekolah yang dari keluarga kaya. 25 remaja merasa apatis, dan 30 remaja terlihat menyimpan sikap negatif lainnya. Sebagian besar remaja mengaku setelah lulus SMA akan sulit menemukan pekerjaan dan akan lebih sulit lagi untuk melanjutkan jenjang pendidikan karena kendala biaya dan lain sebagainya. Hal ini yang membuat mereka cenderung pasif, nerimo, minder, dan perasaan negatif lain yang dapat menurunkan tingkat motivasi berprestasi. Dalam hal inilah dukungan sosial amat diperlukan untuk menjaga motivasi remaja dari kalangan keluarga menengah kebawah agar di kemudian hari mereka dapat keluar dari jeratan kesulitan ekonomi dan mampu menunjukan prestasi serta kontribusi dalam memajukan bangsa.

Berdasarkan data Dinas Kependudukan dan Pencatatan Sipil Kabupaten Kudus pada tahun 2015, jumlah penduduk miskin di Kabupaten Kudus dari tahun ke tahun cenderung mengalami penurunan. Sebelumnya tercatat pada tahun 2013 pernah mengalami peningkatan jumlah yaitu 70.100 jiwa. Hal ini telah menjadi program/kegiatan pemerintah daerah dalam program perlindungan sosial dan pengentasan kemisikinan. Jumlah penduduk miskin dan persentase penduduk miskin tahun 2010 sebesar 70.200 jiwa atau 9,02\% yang diprogramkan turun menjadi 67.091 atau $8,17 \%$ di tahun 2014 (bappeda.kuduskab.go.id.)

Melihat dari data Dinas Kependudukan dan Pencatatan Sipil Kabupaten Kudus, program yang perlu dicanangkan oleh pemerintah daerah adalah menurunkan jumlah penduduk miskin setiap tahunnya. Perkembangan jumlah penduduk miskin atau persentase penduduk miskin dan garis kemiskinan mulai tahun 2010 sampai sekarang terus mengalami penurunan. Usaha pemerintah daerah untuk mengentaskan kemiskinan ini dimulai dengan memberikan dukungan sosial bagi keluarga pra sejahtera.

Di Kabupaten Kudus terdapat beberapa Panti asuhan yang terdiri dari 16 buah Panti Sosial Asuhan Anak, 1 buah Panti Sosial Bina Netra, 1 buah Panti Sosial Bina Karya, sedangkan Panti Sosial Rehabilitasi masih dalam proses perencanaan (bappeda.kuduskab.go.id.). Dengan adanya beberapa panti asuhan ini menunjukkan adanya wujud dukungan sosial dan rasa keperdulian terhadap keluarga pra sejahtera atau keluarga kalangan menengah kebawah.

Menurut Mc Clelland pengertian motivasi berprestasi didefinisikan "where this is high then people have an intense desire to succeed and an equally intense fear of failure.” (Ibrahim, 2014: 17). Mc Clelland menyebutkan sedikitnya ada 5 aspek dalam $\mathrm{N}$-ach atau need for achievement, yaitu: seek achievement, strive to attain goals, want advancement, dan need a sense of accomplishment (Sean, 2013: 23).

Santrock menjelaskan bahwa motivasi berprestasi merupakan keinginan untuk menyelesaikan sesuatu untuk mencapai suatu standar kesuksesan, dan untuk melakukan suatu usaha dengan tujuan untuk mencapai kesuksesan (Sean, 2013: 23). Maslow beranggapan bahwa motivasi seseorang dibentuk melalui kebutuhan-kebutuhan dasarnya yang tersusun secara hierarki. Kebutuhan dasar itu secara berturut-turut adalah kebutuhan biologis, kebutuhan rasa aman, kebutuhan dicintai, kebutuhan harga diri, kebutuhan pengetahuan, kebutuhan keindahan, dan kebutuhan aktualisasi diri (Moeljono, 2001: 108).

McClelland dalam Akbar (2001: 64) mengatakan bahwa ada beberapa faktor yang ikut mempengaruhi motivasi berprestasi seseorang antara lain: (1) Pengalaman pada tahun-tahun pertama kehidupan. Adanya perbedaan pengalaman masa lalu pada setiap orang menyebabkan terjadinya variasi terhadap tinggi rendahnya kecenderungan untuk berprestasi pada diri seseorang. (2) Latar belakang budaya tempat seseorang dibesarkan. Bila dibesarkan dalam budaya yang menekankan pada pentingnya keuletan, kerja keras, sikap inisiatif dan kompetitif, serta suasana yang selalu mendorong individu untuk memecahkan masalah secara mandiri tanpa dihantui perasaan takut gagal, maka dalam diri seseorang akan berkembang hasrat berprestasi yang tinggi. Faktor latar belakang budaya tempat seseorang dibesarkan dapat menjelaskan keterkaitan hubungan kemandirian terhadap motivasi berprestasi. (3) Peniruan tingkah laku (modelling). Melalui modelling, anak mengambil atau meniru banyak karakteristik dari model, termasuk dalam kebutuhan untuk berprestasi jika model tersebut memiliki motivasi dalam derajat tertentu. (4) Lingkungan tempat proses pembelajaran berlangsung. Iklim belajar yang menyenangkan, tidak mengancam, memberi semangat dan sikap optimisme bagi siswa dalam belajar, cenderung akan mendorong seseorang untuk tertarik belajar, memiliki toleransi terhadap suasana kompetisi dan tidak khawatir akan kegagalan. (5) Harapan orangtua terhadap anaknya. Orangtua yang mengharapkan anaknya bekerja keras dan berjuang untuk mencapai sukses akan mendorong anak tersebut untuk bertingkahlaku yang mengarah kepada pencapaian prestasi. 
Dukungan sosial dapat dianggap sebagai sesuatu keadaan yang bermanfaat bagi individu yang diperoleh dari orang lain yang dapat dipercaya. Dari keadaan tersebut individu akan mengetahui bahwa orang lain memperhatikan, menghargai, dan mencintainya. Dukungan sosial adalah suatu pemikiran terbaik sebagai suatu konstruk multidimensional yang terdiri dari komponen fungsional dan struktural. Dukungan sosial merujuk kepada tindakan yang orang lain lakukan ketika mereka menyampaikan bantuan (Roberts \& Gilbert, 2009).

Secara spesifik dukungan sosial dapat diartikan sebagai perasaan nyaman, penghargaan, perhatian atau bantuan yang diperoleh seseorang dari orang lain atau kelompoknya. Dukungan sosial merupakan salah satu fungsi dari ikatan, yang menggambarkan tingkatan kualitas umum dari hubungan interpersonal, dan dukungan ini dapat berasal dari pasangan, anggota keluarga, masyarakat, dan lingkungan sosial (Taylor, 2006: 543).

Dukungan sosial diartikan sebagai kesenangan, bantuan, yang diterima seseorang melalui hubungan formal dan informal dengan yang lain atau kelompok. Sarafino (dalam Kumalasari dan Ahyani (2012) mengemukakan dukungan sosial meliputi empat aspek, yaitu: (1) Dukungan emosional. Dukungan ini melibatkan ekspresi rasa empati dan perhatian terhadap individu sehingga individu tersebut merasa nyaman, dicintai dan diperhatikan. Dukungan ini meliputi perilaku seperti memberikan perhatian dan afeksi serta bersedia mendengarkan keluh kesah orang lain. (2) Dukungan penghargaan. Dukungan ini melibatkan ekspresi yang berupa pernyataan setuju dan penilaian positif terhadap ideide, perasaan dan performa orang lain. (3) Dukungan instrumental. Bentuk dukungan ini melibatkan bantuan langsung, misalnya yang berupa bantuan finansial atau bantuan dalam mengerjakan tugastugas tertentu. (4) Dukungan informasi. Dukungan yang bersifat informasi ini dapat berupa saran, pengarahan dan umpan balik tentang bagaimana cara memecahkan persoalan.

Dukungan sosial dapat diperoleh dari beberapa sumber. Sumber dukungan ini sangat penting dalam membantu siswa meningkatkan prestasi belajar bahasa Inggris. Menurut Goetlieb (dalam Ristianti (2011) menyatakan ada dua macam hubungan dukungan sosial, yaitu hubungan professional yakni bersumber dari orang-orang yang ahli di bidangnya, seperti konselor, psikiater, psikolog, dokter maupun pengacara, serta hubungan non professional, yakni bersumber dari orang-orang terdekat seperti teman, keluarga maupun relasi.

Tujuan penelitian ini adalah untuk mengetahui hubungan dukungan sosial dengan motivasi berprestasi remaja dari keluarga menengah kebawah di Kabupaten Kudus. Sedangkan manfaat secara teoretis penelitian ini diharapkan dapat memberi masukan dalam mengembangkan pendidikan, khususnya tentang dukungan sosial dan motivasi berprestasi. Adapun secara praktis, diharapkan mampu meningkatkan dukungan sosial dan motivasi berprestasi remaja terutama untuk remaja yang hidup dan dibesarkan di kalangan keluarga menengah kebawah. Selain itu diharapkan penelitian ini dapat menjadikan referensi bagi peneliti yang akan datang.

\section{METODE}

Penelitian ini merupakan penelitian korelatif dengan pendekatan kuantitatif yang akan mencari ada atau tidaknya hubungan/pengaruh satu variabel pada variabel lainnya. Populasi yang digunakan pada penelitian ini adalah seluruh remaja berusia 11-18 Tahun dari kalangan keluarga menengah ke bawah di Kabupaten Kudus. Pendapat Sutrisno senada dengan pendapat Sugiyono menjelaskan populasi adalah wilayah generalisasi yang terdiri atas subjek dan objek yang mempunyai kuantitas dan karakteristik tertentu yang ditetapkan oleh peneliti untuk dipelajari dan kemudian ditarik kesimpulan (Sugiyono, 2006 : 55). Metode pengambilan sampel yang digunakan adalah random sampling dengan mengambil 49 remaja secara acak dari berbagai kecamatan di Kabupaten Kudus. Sedangkan metode pengumpulan data yang digunakan adalah Instrumen angket kuesioner skala likert yang berisi sejumlah pertanyaan tertulis yang digunakan untuk memperoleh informasi dari responden. Penelitian ini menggunakan metode pengumpulan data yaitu angket atau kuesioner. Suharsimi menjelaskan bahwa angket atau kuesioner adalah sejumlah pertanyaan tertulis yang digunakan untuk memperoleh informasi dari responden dalam arti laporan mengenai pribadi dirinya, atau hal-hal yang ia ketahui (Suharsimi, 2010: 194).

Gambar 1. Model Penelitian

\begin{tabular}{|c|c|}
\hline $\mathrm{X} 1$ & $\mathrm{X} 2$ \\
Dukungan Sosial & Motivasi Berprestasi \\
\hline
\end{tabular}


Analisis yang digunakan dalam penelitian ini adalah dengan analyze correlate dengan menggunakan aplikasi SPSS, uji korelatif dengan satu variabel independen berupa dukungan sosial dan satu variabel dependen berupa motivasi berprestasi, seperti yang di jelaskan pada gambar 1 .

\section{HASIL DAN PEMBAHASAN}

Pada bagian ini akan dideskripsikan hasil penelitian yang diperoleh dari angket yang disebar kepada 49 remaja dari keluarga menengah ke bawah di Kabupaten Kudus. Dalam angket responden diberikan pernyataan mengenai sikap mereka terhadap item-item pernyataan tersebut yang sudah disediakan alternatif jawaban dengan kategori: Sangat Sesuai (SS), Sesuai (S), Tidak Sesuai (TS), Sangat Tidak Sesuai (STS). Item pernyataan ini merupakan tanggapan/sikap responden mengenai dukungan sosial yang mereka rasakan atau alami, serta peran pentingnya dukungan sosial dalam mendorong mereka meningkatkan motivasi untuk berprestasi.

\subsection{Uji Validitas}

Berdasarkan uji validitas dengan korelasi Bivariate Pearson pada skala dukungan sosial, diperoleh hasil bahwa dari 20 item yang telah diuji dan terdapat 3 item yang gugur karena dari hasil analisis koefisien korelasi kurang dari 0,30. Penentuan item tidak gugur menggunakan ketentuan dari Azwar (2010) yang menyatakan bahwa item pada skala pengukuran dapat dikatakan memuaskan dan memberikan kontribusi yang baik apabila sebesar $\geq 0,30$.

Berdasarkan uji validitas pada skala motivasi berprestasi diperoleh hasil bahwa dari 20 item yang telah diuji terdapat 7 item yang gugur karena dari hasil analisis koefisien korelasi kurang dari 0,30. Penentuan item tidak gugur menggunakan ketentuan dari Azwar (2010) yang menyatakan bahwa item pada skala pengukuran dapat dikatakan memuaskan dan memberikan kontribusi yang baik apabila sebesar $\geq 0,30$

\subsection{Uji Reliabilitas}

Pada angket dukungan sosial, setelah dilakukan pengujian dengan SPSS 17.0 diperoleh koefisien = 0.793. Menurut Azwar (2010) jika koefisien korelasi Alpha lebih dari 0,7 maka menunjukan bahwa reliabilitas alat ukur termasuk dalam kategori baik. Dengan demikian dapat disimpulkan bahwa skala dukungan sosial orang tua yang digunakan sebagai alat ukur dalam penelitian ini juga termasuk dalam kategori baik atau reliabel.

Sedangkan pada Angket motivasi berprestasi setelah dilakukan pengujian dengan SPSS 17.0 diperoleh koefisien $=0.545$. Menurut Azwar (2010) jika koefisien korelasi Alpha lebih dari 0,7 maka menunjukan bahwa reliabilitas alat ukur termasuk dalam kategori baik. Dengan demikian dapat disimpulkan bahwa skala motivasi berprestasi yang digunakan sebagai alat ukur dalam penelitian ini juga termasuk dalam kategori baik atau reliabel.

\subsection{Uji Normalitas}

Analisis persyaratan awal yang dilakukan adalah uji normalitas. Uji normalitas dilakukan dengan program SPSS versi 15 dengan model Kolmogorov Smirnov, salah satu model analisis normalitas yang tersedia dalam program SPSS. Model ini mudah digunakan dan mudah dalam memberikan informasi berkaitan dengan normalitas data.

TABLE I. UJI NORMALITAS

\begin{tabular}{|c|c|c|c|}
\hline & & Dukungan Sosial & Motiv_Prestasi \\
\hline \multicolumn{2}{|c|}{$\mathbf{N}$} & 44 & 44 \\
\hline \multirow{2}{*}{ Normal Parameters ${ }^{a}$} & Mean & 52.2273 & 42.0000 \\
\hline & Std. Deviation & 6.70946 & 4.49289 \\
\hline \multirow[t]{2}{*}{ Differences } & Positive & .078 & .110 \\
\hline & Negative & -.077 & -.134 \\
\hline \multicolumn{2}{|c|}{ Kolmogorov-Smirnov $\mathbf{Z}$} & .515 & .886 \\
\hline
\end{tabular}

Sumber: Data primer yang diolah 2018

Dari tabel di atas terlihat bahwa nila sig. variabel dukungan sosial sebesar $0.954>0.05$, dan nilai sig. variabel motivasi berprestasi sebesar $0.413>0.05$, maka dapat dikatakan bahwa untuk semua variabel telah memenuhi persyaratan uji normalitas karena nilai sig. $>0.05$.

\subsection{Uji Linieritas}

Fungsi uji linearitas adalah untuk mengetahui bentuk hubungan antara variabel bebas atau 
independen dengan variabel terikat atau dependen. Dasar pengambilan keputusan adalah Jika nilai Sig. deviation from linearity $>0,05$, maka terdapat hubungan yang linier antara variabel bebas atau independen dengan variabel terikat atau dependen.

TABLE II. UJI LINIERITAS MOTIVASI BERPRESTASI ( $Y$ ) DENGAN DUKUNGAN SOSIAL (X)

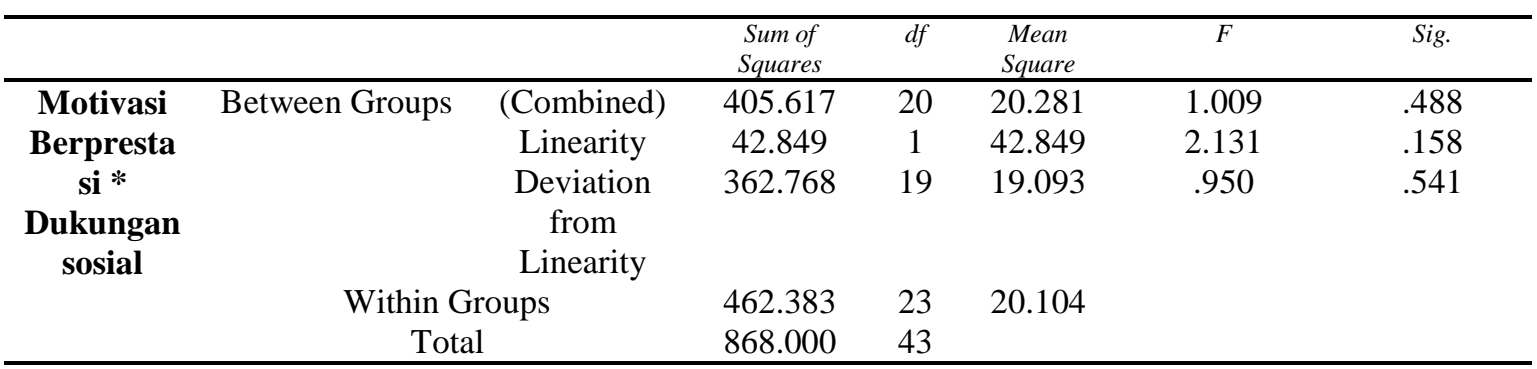

Sumber: Data primer yang diolah 2018

Berdasarkan tabel hasil uji linieritas di atas dapat diketahui bahwa nilai Sig. deviation from linearity antara X1 (dukungan sosial) dengan Y (motivasi berprestasi) adalah sebesar 0,541 > 0,05. maka dapat disimpulkan bahwa terdapat hubungan yang linier antara dukungan sosial dengan motivasi berprestasi.

\subsection{Uji Hipotesis Regresi}

Dengan regresi berganda dapat diketahui ada atau tidaknya pengaruh antara dukungan social terhadap motivasi berprestasi. Persamaan regresi yang didapatkan dari hasil perhitungan adalah sebagai berikut:

TABLE III. ANALISIS KORELASI

\begin{tabular}{ccccc}
\hline & & \multicolumn{3}{c}{ Model Summary } \\
\hline Model & $\mathrm{R}$ & $\mathrm{R}$ Square & Adjusted R Square & Std. Error of the Estimate \\
$\mathbf{1}$ & $.222^{\mathrm{a}}$ & .490 & .027 & 4.43243 \\
\hline
\end{tabular}

Sumber: Data primer yang diolah 2018

Tabel di atas menjelaskan besarnya nilai korelasi (R) yaitu sebesar 0.222 dan dijelaskan besarnya prosentase pengaruh variabel bebas terhadap variabel terikat yang disebut koefisien determinasi yang merupakan hasil dari penguadratan R. Dari data tersebut diperoleh koefisien determinasi (R2) sebesar 0.490, yang mengandung pengertian bahwa pengaruh variabel bebas (dukungan sosial) terhadap variabel terikat (motivasi berprestasi) adalah sebesar 49\%, sedangkan sisanya dipengaruhi oleh variabel yang lain.

Untuk pengujian $\mathrm{F}$ test bisa dilakukan dengan melihat tingkat signifikansi $\mathrm{F}$ hitung. Berikut hasil analisis uji F.

TABLE IV. UJI F

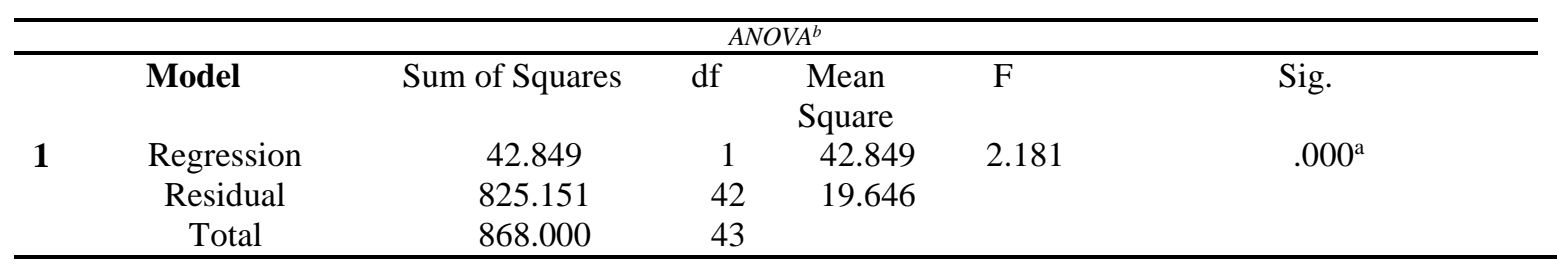

Sumber: Data primer yang diolah 2018

Berdasarkan tabel 4 di atas, maka tingkat signifikansinya adalah 0,000. Karena probabilitas atau signifikansi nilai F Hitung $(0,000)$ lebih kecil dari alpha $(0,05)$, maka Ho ditolak. Dengan demikian, antara variabel Dukungan Sosial (X1) mempunyai pengaruh signifikan terhadap motivasi berprestasi. Analisis regresi linier dalam penelitian ini dijadikan sebagai landasan untuk pemodelan. 


\subsection{Hasil Deskripsi Variabel Dukungan Sosial}

Hasilnya diketahui bahwa dukungan sosial mengarah dari sangat rendah ke sangat tinggi. Tepatnya yaitu $28 \%$ remaja memiliki dukungan sosial pada kategori tinggi, sebesar $19 \%$ pada kategori sedang dan 36\% sangat tinggi. Sedangkan untuk kategori sangat rendah sebesar $6 \%$ dan kategori rendah sebesar $11 \%$. Dengan demikian, dapat dikatakan bahwa remaja dari kalangan keluarga menengah kebawah di Kabupaten Kudus memiliki dukungan sosial yang bergerak dari rendah menuju ke tinggi. Untuk menentukan tinggi rendahnya hasil pengukuran variabel dukungan sosial orang tua digunakan 4 (empat) kategori, yaitu: sangat tidak sesuai, tidak sesuai, sesuai dan sangat sesuai. Dengan adanya skor tertinggi, skor terendah dan banyaknya kategori, maka dapat dihitung lebar interval dengan rumus sebagai berikut:

I $\quad=($ Sekor tertinggi - Sekor terendah $):$ Banyak kategori

$=(182-90): 4$

$=23$

\subsection{Hasil Deskripsi Variabel Motivasi Berprestasi}

Hasilnya diketahui motivasi berprestasi bergerak dari skor sangat rendah sejumlah $8 \%$, skor rendah sebesar $0 \%$, skor sedang sejumlah $15 \%$, kemudian meningkat pada skor tinggi sejumlah $27 \%$, dan yang terakhir yaitu skor sangat tinggi sejumlah $41 \%$. Dengan demikian, dapat dikatakan bahwa motivasi berprestasi siswa tersebar pada tingkatan sangat rendah, rendah, sedang, tinggi dan sangat tinggi. Untuk menentukan tinggi rendahnya hasil pengukuran variabel motivasi berprestasi digunakan 4 (empat) ategori, yaitu: sangat tidak sesuai, tidak sesuai, sesuai dan sangat sesuai. Dengan adanya skor tertinggi, skor terendah dan banyaknya kategori, maka dapat dihitung lebar interval dengan rumus sebagai berikut:

I $\quad=($ Sekor tertinggi - Sekor terendah $):$ Banyak kategori

$=(188-80): 4$

$=27$

\subsection{Pengaruh Dukungan Sosial terhadap Motivasi Berprestasi}

Motivasi berprestasi dikenal sebagai istilah motivasi berprestasi intrinsik dan motivasi berprestasi ekstrinsik. Adapun faktor eksternal motivasi adalah segala sesuatu yang berasal dari luar individu baik yang langsung maupun tidak langsung yang dapat mempengaruhi individu dalam mencapai prestasi belajar di sekolah diantaranya meliputi lingkungan keluarga dalam hal ini dukungan sosial orang tua, sekolah melalui layanan bimbingan belajar oleh guru dan masyarakat.

Beberapa penelitian tentang dukungan sosial menunjukan bahwa dukungan sosial mempunyai pengaruh positif bagi individu dalam menjalani kehidupannya. Seperti meningkatkan perasaan optimis dalam menghadapi masa depan, menambah kesejahteraan psikologis dan kesehatan serta mengurangi pengaruh negatif yang merugikan (House dan Kahn; Johnson dan Johnson; Rodin dan Salovey; Indarjati; Farhati dan Rosyid, dalam Mujiadi, 2003).

Dibutuhkan berbagai upaya untuk meningkatkan motivasi berprestasi dalam diri remaja, salah satunya adalah dengan meningkatkan dukungan sosial orang tua. Menurut Reni Akbar-Hawadi (2003), dukungan dari orang tua dapat mendorong siswa untuk berprestasi. Keluarga atau orangtua merupakan orang-orang terdekat yang dapat mempengaruhi tingkat motivasi berprestasi individu. Dukungan sosial orang tua memiliki peran penting dalam meningkatkan dan mempertahankan motivasi berprestasi remaja. Dukungan sosial orang tua yang terus-menerus diberikan dapat membuat remaja terdorong untuk meningkatkan motivasi berprestasi. Penelitian yang telah dilakukan oleh Maqsud dan Coleman (1993) menunjukkan bahwa dukungan sosial orangtua berpengaruh positif terhadap motivasi berprestasi.

Selain dukungan orang tua, Dukungan sosial dari guru dan teman-teman sebaya siswa juga berperan penting terhadap motivasi berprestasi pada diri remaja. Bagi para siswa, guru adalah seseorang yang memiliki otoritas selain orang tua mereka dalam hal pendidikan. Sedangkan kelompok teman sebaya merupakan kelompok yang memiliki kedekatan khusus satu sama lain sehingga dapat saling mempengaruhi. Lingkungan teman sebaya merupakan suatu kelompok yang baru yang memiliki cirri, norma, kebiasaan yang jauh berbeda dengan apa yang ada dalam lingkungan keluarga. Hubungan kedekatan ini tentunya juga berperan dalam hal pencapaian prestasi yang memuaskan. Hal ini sesuai dengan teori yang dikemukakan oleh Santrock (2003) yang menyatakan bahwa remaja yang memiliki kemampuan yang terbatas untuk menahan diri dari tantangan seringkali akhirnya melakukan tingkah laku beresiko karena desakan teman-teman sebayanya. Dukungan dari teman akrab akan sangat menunjang bagi remaja dari keluarga menengah kebawah untuk melakukan hal yang terbaik dalam hidupnya. Dukungan sosial teman sebaya merupakan dukungan berupa adanya keterlibatan dan penerimaan remaja dalam kelompok sehingga memberikan kesempatan yang sama bagi remaja dari 
keluarga menengah kebawah untuk berinteraksi dan mempelajari kemampuan interpersonal dan kemampuan sosialnya sebagaimana remaja yang dari keluarga berkecukupan.

Berdasarkan hasil analisis diketahui terdapat hubungan dukungan sosial dengan motivasi berprestasi. Hal ini dapat dijelaskan bahwa dukungan sosial sebagai informasi yang diterima dari orang lain bahwa individu tersebut dicintai, diperhatikan, dihargai, dan bernilai dan merupakan bagian dari jaringan komunikasi dan saling dibutuhkan yang didapat dari orang tua, suami, orang yang dicintai, sanak keluarga, teman, hubungan sosial, dan komunitas sehingga dengan adanya dukungan yang baik akan mampu memberi semangat dalam melakukan aktivitasnya, yaitu belajar.

\section{KESIMPULAN}

Secara umum hasil pengukuran di atas membuktikan bahwa hipotesis penelitian yang menyatakan bahwa dukungan sosial berpengaruh positif dan signifikan terhadap motivasi berprestasi remaja dari keluarga menengah kebawah di Kabupaten Kudus. Hal ini didukung oleh hasil penelitian dengan uji statistika F (uji signifikansi) dengan nilai Fhit sebesar 2.181 pada taraf signifikansi $0,000(\mathrm{p}<0,05)$. Remaja yang memiliki motivasi berprestasi tinggi akan berjuang dan berusaha keras untuk meraih sukses. Remaja akan terdorong untuk melakukan aktivitas belajar dengan sebaik-baiknya untuk mencapai prestasi terbaik. Oleh karena itu, motivasi berprestasi tinggi penting dimiliki remaja untuk meraih prestasi yang maksimal.

Sementara itu, koefisien regresi dukungan sosial orang tua bernilai positif yaitu sebesar 0.490, yang berarti bahwa terdapat kontribusi/pengaruh positif dukungan sosial terhadap motivasi berprestasi remaja. Dengan kata lain makin tinggi dukungan sosial yang didapatkan maka akan berdampak pada meningkatnya motivasi berprestasi remaja sebesar 0.490 . Sebaliknya, makin rendah dukungan sosial yang diberikan maka makin rendah pula motivasi berprestasi remaja dari kalangan keluarga menengah ke bawah di Kabupaten Kudus.

Dalam proses pencapaian tujuan pendidikan maupun ekonomi, remaja sebagai tunas bangsa dipengaruhi oleh beberapa faktor internal dan faktor eksternal. Yang dimaksud faktor internal adalah segala sesuatu yang berasal dari dalam diri individu yang mempengaruhi individu dalam proses pencapaian prestasi belajar di sekolah seperti motivasi, minat, bakat dan intelegensi. Motivasi merupakan bagian dari prinsip belajar yang turut menentukan pembelajaran secara efektif (Djamarah, 2000).

Pandangan diatas sejalan dengan apa yang dinyatakan oleh Hawley (Yusuf, 2003) bahwa peserta didik yang memiliki motivasi yang tinggi, belajarnya lebih baik dibandingkan dengan para siswa yang memiliki motivasi rendah. Hal ini berarti remaja yang memiliki motivasi belajar tinggi akan tekun dalam belajar dan terus belajar secara kontinyu tanpa mengenal putus asa serta dapat mengesampingkan hal-hal yang dapat mengganggu kegiatan belajar, sehingga menghasilkan prestasi belajar yang maksimal.

\section{REFERENSI}

Akbar, R, \& Hawadi, (2001) Psikologi Perkembangan Anak, Grasindo, Jakarta.

Daniel, W.W. (1980). Statistika nonparametrik terapan. (Terjemahan Tri Kuntjoro). Jakarta: Gramedia.

Effendi, S. (1982). Unsur-unsur penelitian ilmiah. Dalam Masri Singarimbun (Ed.). Metode penelitian survei. Jakarta: LP3ES.

Gronlund, N.E. \& Linn, R.L. (1990). Measurement and evaluation in teaching. (6 ${ }^{\text {th }}$ ed.). New York: Macmillan.

Gunarsa, dkk, (2008). Psikologi Praktis: anak, remaja, dan keluarga, BPK Gunung Mulia, Jakarta.

Ibrahim Tirimba Ondabu, (2005) A Theory of Human Motivation: The Tirimba Grouping Theory of Motivation, Article · January C DOI: 10.15764/ER.2014.01003.

Lili Garliah dan Ratma Kartika, (2005) "Peran Pola Asuh Orang Tua Dalam Motivasi Berprestasi”, Jurnal Psikologia, Volume I No. 1, Juni 2005.

Moeljono Notosoedirjo, (2001) Kesehatan Mental Konsep \& Penerapan, UMM Press, Malang.

Narulita, M. F. (2005) "Hubungan Antara Self-Regulated Learning dan Presepsi Dukungan Sosial dengan Prestasi Akademik Mahasiswa.” Tesis (tidak diterbitkan). Yogyakarta: Universitas Gadjah Mada.

Prasetyo, D., \& Sukarmin, Y. (2017). Pengembangan model permainan untuk pembelajaran teknik dasar bola basket di SMP. Jurnal Keolahragaan, 5(1), 12-23. DOI: http://dx.doi.org/10.21831/jk.v5i1.12758.

Pritchard, P.E. (1992). Studies on the bread-improving mechanism of fungal alpha-amylase. Journal of Biological Education, 26 (1), 14-17.

Retnawati, H. (2014). Teori respon butir dan penerapannya. Yogyakarta: Nuha Medika. 
S.Taylor, (2006). Health Psychology 6th edition. New York: Mc.Graw Hill.

Santrork, J.W. (2003) “Adolesence: Perkembangan Remaja”, Terj. Rita W. Erlangga, Jakarta

Sean McPheat, (2013) "Personal Confidence \& Motivation”, E-Book, Bookboon.com.

Sri Harmi, (2012) "Hubungan Dukungan Sosial Dan Resiliensi Terhadap Motivasi Berprestasi Siswa Pasca Erupsi Merapi ", Tesis, UMS, Surakarta.

Suyanto, S (2009). Keberhasilan sekolah dalam ujian nasional ditinjau dari organisasi belajar. Disertasi, tidak dipublikasikan. Universitas Negeri Jakarta. 